\title{
Distributive Energy Justice and the Common Good
}

\author{
Anders Melin \\ Recently, philosophers and social scientists have shown increased interest \\ in questions of social, global, and intergenerational distributive justice \\ related to energy production and consumption. However, so far there \\ have been only a few attempts to analyse questions of distributive energy \\ justice from a religious point of view, which should be considered a lack \\ since religions are an important basis of morality for a large part of the \\ world's population. In this article, I analyse issues of distributive energy \\ justice from a Christian theological viewpoint by employing the Catholic \\ common good tradition as a theoretical framework. First, I present and \\ argue for a global and ecological interpretation of the Catholic common \\ good tradition. Then I analyse the implications of such an interpretation \\ on questions of distributive energy justice, focusing on the view of \\ property rights within the Catholic common good tradition. I conclude \\ that, in comparison with Nussbaum's liberal capabilities approach, the \\ common good tradition provides stronger reasons for individuals and \\ groups in more economically developed countries to share their resources \\ and knowledge with individuals and groups in less economically \\ developed countries.
}

\section{Introduction}

Energy is essential for human life, especially in today's economically developed countries, where the population depends on easy access to energy. The science of economics defines energy as 'the capacity to perform work, useful for human beings, thanks to changes in the structure of matter or its position in space. These changes are not free, but imply some cost or effort'. ${ }^{1}$ Energy is created using limited resources, which gives rise to questions of national, global, and intergenerational distributive justice. Moreover, questions of justice also arise due to the negative impacts of energy production and consumption, which are often unequally distributed.

Recently, there has been an increased interest in questions of distributive energy justice among both philosophers and social scientists. ${ }^{2}$ However, so far there has been only

\footnotetext{
1 Astrid Kander, Paolo Malanima, and Paul Warde, Power to the People: Energy in Europe over the Last Five Centuries (Princeton: Princeton University Press 2013), p. 18.

2 See, for example, Benjamin K. Sovacool, Energy \& Ethics: Justice and the Global Energy Challenge, (New York: Palgrave Macmillan 2013); Rosie Day, Gordon Walker, and Neil Simcock, 'Conceptualising energy use and energy policy using a capabilities framework', Energy Policy 93
} 
a few attempts to analyse questions of distributive energy justice from a religious point of view, ${ }^{3}$ which should be considered a lack since religions are an important basis of morality for a large part of the world's population. ${ }^{4}$ In this article, I analyse issues of distributive energy justice from the perspective of Christian theology. Since religions vary, it seems necessary to focus on one specific religious tradition. The common good tradition, especially its contemporary Catholic interpretations, is used as a theoretical framework since it is an important tradition within Christian social thought. Since the Catholic common good tradition rests on a contentious metaphysical worldview, it is questionable whether it can be regarded as an ethical theory that should be universally accepted. ${ }^{5}$ However, the common good tradition is at least relevant for many Christian individuals and communities and possibly some other religious believers. ${ }^{6}$

First, I present and argue for a global and ecological interpretation of the Catholic common good tradition based on a critical reading of some recent contributions to the debate. Then, I discuss the implications of such an interpretation on questions of distributive energy justice, especially regarding the view of property rights within the Catholic common good tradition. In order to clarify the practical relevance of this view of property rights, I compare the Catholic common good tradition with a justice theory that has a more liberal view of property rights and is influential in today's philosophical debate. I have chosen Martha C. Nussbaum's capabilities approach since it has both interesting similarities and differences with the Catholic common good tradition. On the one hand, Nussbaum advocates an Aristotelian view of humans as social beings that closely resembles the one in the Catholic common good tradition, and on the other hand, she describes her approach as a form of political liberalism and gives entitlements a more primary role than duties.

(2016); and Behnam Taebi, Sabine Roeser, The Ethics of Nuclear Energy: Risk, Justice, and Democracy in the post-Fukushima Era, (Cambridge: Cambridge University Press 2015). Our duties to non-human life forms are sometimes discussed within the framework of justice, see, Brian Baxter, A Theory of Ecological Justice (New York: Routledge 2005). However, due to the space limitations, I do not include the moral relationship to non-humans in my analysis here.

3 Some examples are the following: Pontifical Council for Justice and Peace, Energy, Justice, and Peace: A Reflection on Energy in the Current Context of Development and Environmental Protection, (New York: Paulist Press, 2014); Sigurd Bergmann, Religion, Space, and the Environment (New Brunswick, London: Transaction Publishers, 2014), pp. 315-322; and Larry L. Rasmussen, 'Energy: the Challenges to and from Religion', Zygon, 46:4 (December 2011).

4 William Schweiker (ed.), The Blackwell Companion to Religious Ethics (Malden, MA: Blackwell 2008).

5 David S. Oderberg, "The Metaphysical Foundations of Natural Law" in Natural Moral Law in Contemporary Society, edited by Holger Zaborowski (Washington, D.C.: Catholic University of America Press 2010)

6 Daniel P. Scheid argues that the common good tradition shares many characteristics with ethical concepts within Hinduism, Buddhism, and American Indian Traditions. See Daniel P. Scheid, The Cosmic Common Good: Religious Grounds for Ecological Ethics (Oxford: Oxford University Press, 2016). 


\section{A Global and Ecological Interpretation of the Common Good}

The common good tradition has a long history within Christianity, especially within Catholicism, although it is also found in the theologies of the Protestant Reformers and in contemporary Protestant ethics.7 The notion of the common good has several different meanings. It is sometimes used to denote the noble and immaterial ends that humans should strive for, such as justice. Steven A. Long, for example, describes the common good as primarily a theological and moral principle. In order for something to be a genuine common good, it should participate in the ultimate common good of the universe that is God. According to the Catholic understanding, as formulated by Thomas Aquinas, all things are directed to God as their end. ${ }^{8}$ There is a teleological hierarchy of common good that ends in the celestial city of the saints. ${ }^{9}$

Other interpretations of the notion of the common good are more focused on the material well-being of humans. Some interpretations limit the common good to those goods that can only be held or enjoyed in common, such as clean air, whereas other interpretations include all natural resources that humans need for their survival and wellbeing, even those that individuals can enjoy in isolation. ${ }^{10}$ John Hart, for example, offers two meanings for the term: (1) the collective well-being of a community and (2) the goods of the earth that to some extent should be shared. ${ }^{11}$ Hart claims that natural resources should be considered common goods when they are needed for the subsistence and wellbeing of the members of the community; the basic needs of all its members should be met. In addition, we should also show concern for future generations. ${ }^{12} \mathrm{~A}$ similar interpretation of the Catholic common good tradition is put forward by Daniel P. Scheid, who argues that the common good encompasses those material goods that every individual needs, such as food and clothing. ${ }^{13}$ According to Scheid, the belief in the inherent dignity of all humans based on the theological doctrine that they are created in the image of God - is an important aspect of the Catholic common good tradition. ${ }^{14}$ Moreover, the mainstream Catholic view, which is influenced by Aristotelian anthropology, regards the human person as a unit of body and soul; therefore, it is necessary to recognize that humans have both bodily and spiritual needs. ${ }^{15}$

\footnotetext{
7 See, for example, Benjamin Myers, 'Rights, Resistance and the Common Good: Calvin's Political Theology', Uniting Church Studies, 17:1 (2011); Wanda Deifelt, 'Seeking the Common Good: Lutheran Contributions to Global Citizenship', Intersections, 29 (2009); and Marcia Pally, The New Evangelicals: Expanding the Vision of the Common Good (Rapids, MI: Eerdmans, 2011).

8 Steven A. Long, 'Understanding the Common Good', Nova et Vetera, 16:4 (2018), p. 1143.

${ }^{9}$ Long, 'Understanding the Common Good', p. 1148.

10 Waheed Hussain, 'The Common Good' in Stanford Encyclopedia of Philosophy, edited by Edward N. Zalta (published 2018-02-26), John Hart, Sacramental Commons: Christian Ecological Ethics (Lanham, MA: Rowman \& Littlefield, 2006).

11 Hart, Sacramental Commons, p. 147.

12 Ibid., pp. 149-152.

13 Daniel P. Scheid, The Cosmic Common Good: Religious Grounds for Ecological Ethics (Oxford: Oxford University Press, 2016), p. 16.

14 Scheid, The Cosmic Common Good, pp. 15-16.

15 Joseph Koterski, 'Human Nature from a Catholic Perspective', American Journal of Economics and Sociology, 71 (4) 2012, pp. 810-812.
} 
Since this article is concerned with the material welfare of humans in relation to energy production and consumption, I focus on material well-being in my interpretation of the concept of the common good. I employ a wide interpretation that encompasses both goods that members of a society share and goods that individuals can enjoy in isolation and that are necessary for their individual subsistence and well-being. This interpretation is based on the belief in God as the proper owner of all of earth's resources. From a theological point of view, these resources are God's gift to all of humanity (see below).

One central element in both classical and contemporary interpretations of the Catholic common good tradition is the belief that promoting the common good requires prioritizing the needs of individuals and the community over individual preferences..$^{16}$ Although the individual is important, he or she has both civic and Christian responsibilities since he or she exists in social relationships. The individual has a duty to work for the common good, even at his or her own expense. ${ }^{17}$ While more individualistic views of society see the good of a community primarily as the sum of its members' interests, the Catholic common good tradition puts more emphasis on cooperation and shared social objectives. ${ }^{18}$

Recently, the Christian common good tradition has been called into question for arguably promoting the self-interest of certain social groups. For example, in the history of Christianity, women have often been encouraged to a greater extent than men to neglect their individual welfare for the sake of the good of the family or community. ${ }^{19}$ However, modern interpreters of the Catholic common good tradition consider this critique and emphasize respect for individual human dignity and human rights as an important part of the tradition. ${ }^{20}$

The Catholic common good tradition differs from the natural right tradition, which is an important point of departure for contemporary liberal philosophers. While the former considers humans social by nature and created to live in communities, the latter sees humans as pre-political individuals that have certain rights (often understood as negative rights). The natural rights tradition also sees society as based on a contract between individuals, who are not by necessity social. Further, in the Catholic common good tradition, the individual's duties to the community have a higher priority than his or her rights, which are regarded as means necessary to fulfil duties. The natural right tradition

16 Hart, Sacramental Commons, pp. 149-151; George J. Lavere, 'The problem of the common good in Saint Augustine's Civitas Terrena', Augustinian Studies, 14 (1983); Richard A. Crofts, 'The Common Good in the Political Theory of Thomas Aquinas', The Thomist: A Speculative Quarterly Review, 37:1 (January 1973).

17 Lavere, 'The problem of the common good in Saint Augustine's Civitas Terrena'; Crofts, 'The Common Good in the Political Theory of Thomas Aquinas'.

18 John Langan, S.J. 'Common Good' in A New Dictionary of Christian Ethics, edited by John

Macquarrie, James Childress (London: SCM Press, 1986), p. 102.

${ }^{19}$ For a feminist critique of the common good tradition, see, for example, Susanne DeCrane, Aquinas, Feminism, and the Common Good, (Washington, D.C.: Georgetown University Press, 2004). 20 See, for example, David Hollenbach, The Common Good and Christian Ethics (Cambridge: Cambridge University Press, 2002); Eric Mount, Jr., Covenant, Community and the Common Good: An Interpretation of Christian Ethics (Cleveland, OH: The Pilgrim Press, 1999). 
instead emphasizes individual rights. ${ }^{21}$ Of course, it is a contentious issue which of the two traditions is the most tenable and convincing. However, it can be argued that the common good tradition fits better with the Christian tradition as a whole since it is more in line with the Biblical message. In both the Old and the New Testament, covenant is a central concept and a point of departure for moral rules. The Bible stresses that humans are created to live in community with one another and with God. ${ }^{22}$

One element of the Catholic common good tradition that is especially relevant to distributive justice is its view on property rights. The ethics of property within this tradition rests on two pillars: the affirmation of private property and the belief in the universal destination of goods. This double basis is found already in the writings of Thomas Aquinas, and it is further developed in some papal encyclicals and other important documents from the Catholic Church from the end of the nineteenth century onwards. ${ }^{23}$ On the one hand, the Catholic common good tradition affirms the importance of private property. Since humans are created as not only spiritual but also physical beings, they need certain external goods for their survival. Humans have a duty of selfpreservation and, therefore, the right to such goods. Moreover, as the image of God, humans have sovereignty over the earth and authorization to place necessary goods in their service, which is generally accomplished through work. In this way, humans acquire property. ${ }^{24}$ Furthermore, the right to property is regarded as necessary for the autonomy of persons and their ability to function in society - it is essential for human freedom. ${ }^{25}$

On the other hand, the natural right to private property is not absolute in the Catholic common good tradition; it is 'subordinate to the universal destination of goods', that is, the common right of all people to usage of goods. Property rights should always be exercised for the common good. ${ }^{26}$ However, given the human condition, the Catholic tradition argues that common property and lack of private property rights would lead to sloth and disorder. Private property is therefore the best means for achieving the common good. ${ }^{27}$ Nevertheless, if proprietors forget their social duties, expropriation can sometimes be justified. ${ }^{28}$

21 J. Bryan Hehir, 'The modern Catholic Church and human rights', in Christianity and Human Rights: An Introduction, edited by John Witte, Jr., Frank S. Alexander (Cambridge: Cambridge University Press, 2010), pp. 118-119.

22 Mount, Covenant, Community, and the Common Good, pp. 14-15.

${ }^{23}$ Manfred Spieker, 'The Universal Destination of Goods: The Ethics of Property in the Theory of a Christian Society', Journal of Markets \& Morality, 8 (2), Fall 2005, pp. 334-337; B. Andrew Lustig, 'Property and Justice in the Modern Encyclical Literature', The Harvard Theological Review, 83:4 (Oct 1990); Thomas Aquinas, Summa Theologica (translated by fathers of the English Dominican Province), (Notre Dame, IN: Ave Maria Press, 1948), 2a-2ae, q. 32, a. 5, ad. 2; Leo XIII, Rerum Novarum, 1891; Paul VI, Gaudium et Spes, 1965; John Paul II, Laborem Exercens, 1981; and John Paul II, Centesimus Annus, 1991.

24 Spieker, 'The Universal Destination of Goods', p. 336; John Paul II, Laborem Exercens, § 12; John

Paul II, Centesimus Annus, § 31.

25 Paul VI, Gaudium et Spes, § 71.

26 Spieker, 'The Universal Destination of Goods', pp. 336-337; John Paul II, Centesimus Annus, § 30;

Pontifical Council for Justice and Peace, Compendium of the Social Doctrine of the Church, 2004, §328329.

27 Spieker, 'The Universal Destination of Goods', p. 337.

28 Ibid., p. 341. 
In today's theological debate, the principle of universal destination of goods is also applied on the global level. Traditionally, the nation-state was conceived of as the boundary for the common good. However, after World War II, an international or global interpretation of the common good concept has become increasingly prevalent. ${ }^{29}$ Such an interpretation is put forward in several papal encyclicals, ${ }^{30}$ as well as by individual Catholic theologians. ${ }^{31}$ For example, the contemporary theologian David Hollenbach argues for a conception of the common good that includes the whole world. He claims that in the current state of affairs, the well-being of individuals in different parts of the world is increasingly interdependent. Actions conducted in one country may affect both the economic status of individuals in other countries and the environmental conditions under which they live. Hollenbach argues that current trends of globalization call for a widened understanding of the community of which we are a part. ${ }^{32}$ The realization of the global common good requires respecting the civil and political rights, as well as the social and economic rights, of all humans on the planet. ${ }^{33}$ Another important aspect of the Catholic common good tradition that is relevant for issues of global justice is the preferential option for the poor, which demands special concern for underprivileged groups in less economically developed countries. ${ }^{34}$

I agree with Hollenbach that a contemporary interpretation of the Catholic common good tradition needs to recognize that we also have duties to individuals living in other parts of the world. However, the increased interaction today between individuals in different countries and continents is neither a necessary nor a sufficient reason for concluding that we have duties to citizens in other nation-states. Since the Catholic common good tradition is not a contractarian theory, social cooperation with people in other parts of the world is not a precondition for having duties to them. Moreover, the mere fact that we consume products manufactured by people in other countries is not a sufficient reason for concluding that we have such duties. From a rational self-interest standpoint, we have limited reasons to be concerned about humans in other countries. Instead, from the Catholic common good perspective, our duties to people in other parts of the world follow from the belief that all humans have dignity since they are created in the image of God.

In addition, contemporary Catholic social teaching often includes an ecological interpretation of the common good tradition, which treats the environment as a common resource for all humans. ${ }^{35}$ As seen above, contemporary theologians such as Hart and Scheid argue that the earth as a whole with all its natural resources is a common good that should be preserved for the sake of humanity, both current and future humans. In light of

29 William A. Barbieri, Jr., 'Beyond the Nations: The Expansion of the Common Good in Catholic Social Thought', The Review of Politics, 63:4 (Autumn, 2001).

30 See, for example, John XXIII, Pacem in Terris, 1963; John Paul II, Sollicitudo Rei Socialis, 1987; and

Francis, Laudato Si', 2015.

31 See, for instance, Jacques Maritain, Man and the State (Chicago: University of Chicago Press, 1951)

and John Courtney Murray, We Hold These Truths: Catholic Reflections on the American Proposition

(New York: Sheed and Ward, 1960)

32 Hollenbach, The Common Good and Christian Ethics, pp. 212-217.

33 Ibid., pp. 220-227.

34 See, for example, Francis, Evangelii Gaudium, § 194.

35 See, for example, Pontifical Council for Justice and Peace, Compendium of the Social Doctrine of the

Church, § 466-467; Francis, Laudato Si'. 
the contemporary scientific understanding of humanity's dependency on nature, it seems necessary to include natural resources among those goods that humans need for their wellbeing and to acknowledge the ways in which environmental destruction threatens the welfare of humans.

To conclude, the theoretical framework of this article is based on a global and ecological interpretation of the Catholic common good tradition, focused on the material well-being of humans. Accordingly, the protection of the environment is a precondition for the well-being of communities and their individuals. The resources of the earth are regarded as parts of the common good. Therefore, property rights are not seen as absolute but as subordinate to the material well-being of all humanity. Out of respect for their human dignity, both current and future humans should be given the opportunity to satisfy their material needs. As we will see in the next section, this interpretation of the Catholic common good tradition has important implications for distributive energy justice.

\section{Implications for Energy Justice}

The Catholic common good tradition views property rights differently than the liberal theories of justice that dominate today's philosophical debate. ${ }^{36}$ As previously mentioned, the Catholic common good tradition is based on the view that God is the proper proprietor of the earth's resources, which makes property rights subordinate to the common good.

A report on energy and justice by The Pontifical Council for Justice and Peace explicitly relates the question of property rights to questions of energy production and consumption. It affirms the view that energy should be regarded as a common good - a gift from God to the whole of humanity. Therefore, every human is called to share energy resources with those who need it. ${ }^{37}$ According to the report, the view that energy and other natural resources are a common good leads to a demand for redistribution, both at the national and the global level. ${ }^{38}$ Moreover, it is important to transfer scientific and technological knowledge to less economically developed countries. ${ }^{39}$

The Pontifical Council for Justice and Peace seems right in pointing out that the Catholic common good tradition leads to a demand for redistribution of energy sources at both the national and global level. As stated in the scientific debate on energy justice, there are large inequalities in energy consumption, both within and between countries. While members of the richest segments of the population in some of the more economically developed countries drive around in SUVs and travel to Thailand or Hawaii on vacation, members of the poorest segments can barely afford to pay the electricity bill. Energy poverty is a common phenomenon also in many of the more economically developed

36 Some other positions within contemporary political philosophy, such as communitarianism and Marxism, have a view of property rights that more closely resembles the common good tradition than liberalism. However, since they are less influential in today's debate and since I do not have space here for a more detailed comparison of the common good tradition with these forms of political philosophy, I limit this study to a comparison with a liberal view of property rights.

37 Pontifical Council for Justice and Peace, Energy, Justice, and Peace, pp. 2-4.

38 Ibid., p. 24.

39 Ibid., p. 65. 
countries. ${ }^{40}$ The differences are even more apparent if one compares the energy consumption in more and less economically developed countries. In the latter group of countries, around 1.1 billion live without electricity and 2.8 billion lack access to clean cooking facilities. ${ }^{41}$ A large part of the world's population is dependent on wood, charcoal, and dung for cooking, which causes a very high number of premature deaths each year due to indoor air pollution. ${ }^{42}$

From the Catholic common good perspective, countries cannot claim an exclusive right to certain resources just because they happen to own them. Individuals in less economically developed countries are entitled to a higher energy consumption than they currently have to live a dignified life, and more economically developed countries are required to share some of their resources, both material resources and technological expertise.

Moreover, according to the Catholic common good tradition, all humans have the right to environmental conditions that make it possible to live a dignified life. Therefore, we should take into account the environmental consequences of energy production and consumption - in terms of their unequal distribution between countries as well as their effect on future generations. For instance, more economically developed countries have higher greenhouse gas (GHG) emissions. At the same time, the less economically developed countries often suffer more from the negative environmental effects of global warming - such as increased frequencies of heat waves, droughts, and floods - partly because they have lower capacity to adapt to climate change. They are also likely to be more seriously affected by climate change in the near future. The Intergovernmental Panel on Climate Change's fifth assessment report states that in the coming decades global warming is likely to decrease food security and make poverty reduction more difficult in the developing world. 43 We also need to consider that our GHG emissions will have consequences for the ecosystems several thousand years into the future and will therefore have a significant negative impact on future humans. ${ }^{44}$

${ }^{40}$ Harriet Thomson, Carolyn Snell, and Stefan Bouzarovski, 'Health, Well-Being and Energy Poverty in Europe: A Comparaive Study of 32 European Countries', International Journal of Environmental Research and Public Health, 14:6 (2017).

41 The webpage of the International Energy Agency, https://www.iea.org/energyaccess/ (accessed 2018-06-20).

42 Benjamin K. Sovacool and Michael H. Dworkin, Global Energy Justice: Problems, Principles, and Practices, (Cambridge, UK: Cambridge University Press, 2014), pp. 228-229.

43 IPCC, 'Summary for policymakers', in Climate Change 2014: Impacts, Adaptation, and Vulnerability. Par A: Global and Sectoral Aspects. Contribution of Working Group II to the Fifth Assessment Report of the Intergovernmental Panel on Climate Change, edited by C.B. Field, V.R. Barros, D.J. Dokken, K.J. Mach, M.D. Mastrandea, T.E. Bilir, M. Chatterjee, K.L. Ebi, Y.O. Estrada, R.C. Genova, B. Girma, E.S. Kissel, A.N. Levy, S. MacCracken, P.R. Mastrandea, and L.L. White, (Cambridge, UK and New York, NY: Cambridge University Press, 2014).

44 M. Colllins, R. Knutti, J. Arblaster, J.-L. Dufresne, T. Fichefet, P. Friedlingstein, X. Gao, W.J. Gutowski, T. Johns, G. Krinner, M. Shongwe, C. Tebaldi, A.J. Weaver, and M. Wehner, 'Long-term Climate Change: Projecctions, Commitments and Irreversibility', in Climate Change 2013: The Physical Science Basis. Contributions of Working Group 1 to the Fifth Assessment Report of the Intergovernmental Panel on Climate Change, edited by T.F. Stocker, D. Qin, G.-K. Plattner, M. Tignor, S.K. Allen, J. Boschung, A. Nauels, Y. Xia, V. Bex, and P.M. Midgley (Cambridge: Cambridge University Press, 2013). 
The Catholic common good tradition obligates us to develop an energy system that is just from a social, global, and intergenerational perspective. To live a dignified life, both current and future humans in different parts of the world need access to energy as well as decent environmental conditions. We must phase out fossil fuels, or at least drastically reduce their use, before the middle of this century in order to save large parts of the planet from becoming uninhabitable in the future. Fossil fuels will have to be replaced by renewables, such as wind and solar power as well as biofuels; however, according to common predictions, it will be difficult to replace fossil fuels completely with renewables. It is likely that we will have to reduce our energy consumption. ${ }^{45}$ Since the earth's population is expected to continue increasing, although at a less rapid pace, ${ }^{46}$ the global per capita consumption of energy in 2050 needs to be significantly lower than the present. Simultaneously, individuals in less economically developed countries need to increase significantly their use of energy to live a dignified life. Accordingly, most individuals in the more economically developed countries have to reduce drastically their energy use. This requires a radical shift of life style - and perhaps also the current economic and political systems - which is likely to be unpopular and difficult to accomplish. Nevertheless, it is warranted from the perspective of the Catholic common good tradition.

Nussbaum's capabilities approach can also justify certain forms of resource redistribution. However, since it regards entitlements as more fundamental than responsibilities, it is questionable whether it can achieve the same results as the Catholic common good tradition. Nevertheless, the capabilities approach is rather similar to the Catholic common good tradition since both theories draw inspiration from Aristotle's view of humans and society. ${ }^{47}$ Nussbaum's point of departure is an Aristotelian conception of individuals as social by nature. ${ }^{48}$ At the same time, she states that her capabilities approach is a form of political liberalism in accordance with John Rawls's definition; namely, the list of capabilities should be based on an 'overlapping consensus' between different 'comprehensive doctrines' - that is, different philosophical or religious worldviews. ${ }^{49}$ Furthermore, entitlements are more fundamental than duties in her approach (see below), which gives it a clearly liberal character. ${ }^{50}$

The key element of Nussbaum's theory of justice is her list of capabilities. She argues that the minimal requirement of justice is that each individual reaches a threshold level of the following ten capabilities: (1) Life, (2) Bodily Health, (3) Bodily Integrity, (4) Senses, Imagination, and Thought, (5) Emotions, (6) Practical Reason, (7) Affiliation, (8) Other Species, (9) Play, and (10) Control over One's Environment (Political and Material).

\footnotetext{
45 Richard Heinberg and David Fridley, Our Renewable Future: Laying the Path for One Hundred Percent Clean Energy, (Washington, D.C.: IslandPress, 2016), pp. 7-9.

46 United Nations, Department of Economic and Social Affairs, Population Division, World Population Prospects: the 2017 Revision, Key Findings and Advance Tables, Working Paper No. ESA/P/WP/248 (UN: New York, 2017).

47 Mary M. Keys, Aquinas, Aristotle and the Promise of the Common Good, (Cambridge: Cambridge University Press, 2008); Martha C. Nussbaum, Frontiers of Justice: Disability, Nationality, Species Membership, (Cambridge, MA, London, UK: The Belknap Press of Harvard University Press, 2006), pp. 273-274.

48 Nussbaum, Frontiers of Justice, pp. 273-274.

49 Martha C. Nussbaum, Women and Human Development: The Capabilities Approach, (Cambridge:

Cambridge University Press, 2000), p. 5.

50 Nussbaum, Frontiers of Justice, pp. 279-281.
} 
Nussbaum sees the different capabilities as separate components, so a lack of one of them cannot be compensated for by a high level of another. ${ }^{51}$ Nussbaum's list of capabilities is closely related to her concept of dignity since she considers the possession of these capabilities necessary for living with human dignity. In order to determine which capabilities are essential, we should find a way of living and acting that is compatible with human dignity. ${ }^{52}$

Further, in Nussbaum's most detailed discussion of dignity in chapter 14 of Human Dignity and Bioethics: Essays Commissioned by the President's Council on Bioethics, she endorses an Aristotelian-Marxian view of dignity. Nussbaum states that such a conception recognizes that humans are vulnerable and needy beings who require help from others. ${ }^{53}$ Simultaneously, she recognizes that any conception of dignity used to form the basis of political principles should not be linked to any specific philosophical and religious worldview. Therefore, it cannot be based on an Aristotelian view of human flourishing. ${ }^{54}$ In Creating Capabilities, Nussbaum puts forward another conception of human dignity that seems to be more compatible with her framework of political liberalism. She describes the following characteristics as important for her view of dignity: (1) respect, beings with dignity should be respected by others; (2) agency, people's ability to manage their own lives should be promoted; and (3) equality, all individuals are worthy of the same respect. ${ }^{55}$

As for Nussbaum's view on property rights, she does not include the ability to hold property in her earlier formulation of her list of capabilities. However, in Women and Human Development, she describes the ability to hold property as part of the capability to have control over one's environment. Moreover, she states that it is not only a question of formal ability but also a question of real opportunity. ${ }^{56}$ In other words, everyone should have the right to actually own a certain amount of property. However, in Creating Capabilities, Nussbaum has omitted the latter statement, so it is unclear whether she still maintains this view. ${ }^{57}$ For the sake of the argument, I assume that she does.

Concerning Nussbaum's view of global justice, she claims in Frontiers of Justice that our world is not minimally just unless all the people of the world reach a certain threshold of the ten capabilities. ${ }^{58}$ According to Nussbaum, entitlements are more fundamental than duties, which are derived from entitlements. All humans deserve to live a dignified life, and this moral claim justifies a collective obligation for rich individuals and countries to help poor individuals and countries. ${ }^{59}$ Nussbaum argues that all humans have equal dignity, which justifies equal political rights for all citizens. However, the fact that all humans have equal dignity does not justify equal distribution of property. Nussbaum

\footnotetext{
51 Nussbaum, Women and Human Development, pp. 78-81.

52 Nussbaum, Frontiers of Justice, pp. 161-162.

53 Martha C. Nussbaum, 'Chapter 14: Human Dignity and Political Entitlements' in Human Dignity and Bioethics: Essays Commisioned by the President's Council on Bioethics, (Washington, 2008), p. 3.

54 Nussbaum, 'Human Dignity and Political Entitlements', p. 4.

55 Martha C. Nussbaum, Creating Capabilities: The Human Development Approach (Cambridge, MA: The Belknap Press of Harvard University Press, 2011), pp. 29-31.

56 Nussbaum, Women and Human Development, p. 80. See also Rutger Claassen, 'The Capability to Hold Property', Journal of Human Development and Capabilities, 16:2 (2015), pp. 222-223.

57 Nussbaum, Creating Capabilities, p. 34.

58 Nussbaum, Frontiers of Justice, p. 281.

59 Ibid., pp. 279-281.
} 
argues that a dignified human life only requires a certain threshold of material property, not an equal amount of property for all citizens. ${ }^{60}$

Nussbaum argues that rich nations ought to give a substantial part of their GDP to poor countries. This demand follows from the principle of respecting human dignity. ${ }^{61}$ Further, Nussbaum claims that we need some system of global governance. This system should include a tax on the more economically developed countries to promote the development of less economically developed parts of the world. ${ }^{62}$ In addition, Nussbaum states that the focus for both institutions and individuals should be on the groups in society with an especially low quality of life, as measured by the capabilities list. ${ }^{63}$

Both the common good tradition and Nussbaum's capabilities approach argue for a redistribution of resources. Nussbaum's view that a dignified human life requires a certain threshold of property can justify a redistribution, at least to some extent. However, the two approaches differ since Nussbaum regards entitlements as more fundamental than duties. Her approach does not address whether (or to what extent) we are justified in infringing upon the property rights of individuals in rich parts of the world in order to realize the capabilities of individuals in poor parts. Nussbaum argues for a global tax that transfers resources from the rich parts of the world to the poor parts, but it is unclear if such a tax can be justified since she regards the capability to have control over one's environment as equally important as the capabilities of life and bodily health. In contrast, the Catholic common good tradition subordinates property rights to the common good.

Furthermore, unlike the Catholic common good tradition, the capabilities approach is intended to be only a minimal theory of justice that can be supported by different comprehensive doctrines. ${ }^{64}$ It is not concerned with how one should handle questions of distribution above the threshold level for the different capabilities. Although the Catholic common good tradition emphasizes the satisfaction of needs, it can still justify redistributions between individuals whose basic needs are satisfied if the current distribution is considered unjust. For example, an unjust distribution could be a consequence of unjust conditions, such as the exploitation of one country by another.

Furthermore, there is a certain inconsistency in Nussbaum's description of human persons and human dignity. In some contexts, she argues for an Aristotelian conception of the human person and human dignity, but her commitment to political liberalism seems to force her to accept a 'thinner' conception. In Creating Capabilities, Nussbaum puts forward a view of dignity that seems more metaphysically neutral - centred on the concepts of respect, agency, and equality. However, there are many different interpretations of what these concepts mean. An interpretation that is compatible with different comprehensive doctrines is bound to be rather diluted. Since Nussbaum's view of dignity justifies her list of capabilities, her unclear conception of dignity makes it doubtful whether her view on property rights can be justified.

60 Nussbaum, Frontiers of Justice, p. 293.

61 Ibid., pp. 316-317.

62 Ibid., pp. 319-320.

63 Ibid., pp. 320-323.

64 Nussbaum, Women and Human Development, p. 75. 


\section{Conclusions}

I argue for energy distributions based on a global and ecological interpretation of the Catholic common good tradition. According to such an interpretation, the moral belief that all humans are created in the image of God requires us to also show concern for groups and individuals in other parts of the world. Moreover, in light of the current ecological awareness, we ought to regard natural resources as an important part of the common good that we need to protect.

I conclude that the Catholic common good tradition demands an energy system that is just from a social, global, and intergenerational point of view. Concern for future generations requires a significant reduction of the use of fossil fuels, which is likely to lead to a reduction of the global energy consumption per capita. At the same time, many individuals in the poor parts of the world need to increase their energy use to live a dignified life, which demands a significant reduction of energy consumption in the rich parts of the world.

In comparison with Nussbaum's capabilities approach - which is one of the most influential liberal theories of justice within the current philosophical debate - the Catholic common good tradition provides us with stronger reasons to redistribute energy and other natural resources between people in different parts of the world. Nussbaum's prioritization of entitlements instead of duties restricts the possibility of justifying limitations to individual property rights for the sake of redistributing resources. ${ }^{65}$

Anders Melin, Malmö University anders.melin@mau.se

\section{Bibliography}

Aquinas, Thomas. Summa Theologica (translated by fathers of the English Dominican Province). Notre Dame, IN: Ave Maria Press, 1948.

Barbieri, William A., Jr. 'Beyond the Nations: The Expansion of the Common Good in Catholic Social Thought', The Review of Politics, 63:4 (Autumn, 2001), pp. 723-754.

Baxter, Brian. A Theory of Ecological Justice. New York: Routledge, 2005.

Bergmann, Sigurd. Religion, Space, and the Environment. New Brunswick, London: Transaction Publishers, 2014.

Claassen, Rutger. 'The Capability to Hold Property', Journal of Human Development and Capabilities, 16:2 (2015), pp. 220-236.

Colllins, M., R. Knutti, J. Arblaster, J.-L. Dufresne, T. Fichefet, P. Friedlingstein, X. Gao, W.J. Gutowski, T. Johns, G. Krinner, M. Shongwe, C. Tebaldi, A.J. Weaver and M. Wehner, 'Long-term Climate Change: Projections, Commitments and Irreversibility', in Climate Change 2013: The Physical Science Basis. Contributions of Working Group 1 to the Fifth Assessment Report of the Intergovernmental Panel on Climate Change, edited by T.F. Stocker,

65 This article has been written as part of a research project on energy and justice, funded by the Swedish Research Council, Dnr 421-2013-781. 
D. Qin, G.-K. Plattner, M. Tignor, S.K. Allen, J. Boschung, A. Nauels, Y. Xia, V. Bex, P.M. Midgley. Cambridge: Cambridge University Press 2013.

Crofts, Richard A. 'The Common Good in the Political Theory of Thomas Aquinas', The Thomist: A Speculative Quarterly Review, 37:1 (January 1973), pp. 155-173.

Day, Rosie, Gordon Walker, Neil Simcock, 'Conceptualising energy use and energy policy using a capabilities framework', Energy Policy 93 (2016), pp. 255-264.

DeCrane, Susanne M. Aquinas, Feminism, and the Common Good. Washington, D.C.: Georgetown University Press, 2004.

Deifelt, Wanda. 'Seeking the Common Good: Lutheran Contributions to Global Citizenship', Intersections, 29 (2009), pp. 22-27.

Francis. Evangelii Gaudium. 2013.

Francis. Laudato Si. 2015.

Hart, John. Sacramental Commons: Christian Ecological Ethics. Lanham, MA: Rowman \& Littlefield 2006.

Hehir, J. Bryan. 'The modern Catholic Church and human rights' in Christianity and Human Rights: An Introduction, edited by John Witte, Jr., Frank S. Alexander. Cambridge: Cambridge University Press 2010, pp. 113-134.

Heinberg, Richard and David Fridley. Our Renewable Future: Laying the Path for One Hundred Percent Clean Energy. Washington, D.C.: IslandPress 2016.

Hollenbach, David. The Common Good and Christian Ethics. Cambridge: Cambridge University Press 2002.

Hussain, Waheed. 'The Common Good' in Stanford Encyclopedia of Philosophy, edited by Edward N. Zalta (published 2018-02-26).

IPPC, 2014: Summary for policymakers, In: Climate Change 2014: Impacts, Adaptation, and Vulnerability. Par A: Global and Sectoral Aspects. Contribution of Working Group II to the Fifth Assessment Report of the Intergovernmental Panel on Climate Change, edited by C.B. Field, V.R. Barros, D.J. Dokken, K.J. Mach, M.D. Mastrandea, T.E. Bilir, M. Chatterjee, K.L. Ebi, Y.O. Estrada, R.C. Genova, B. Girma, E.S. Kissel, A.N. Levy, S. MacCracken, P.R. Mastrandea, and L.L. White. Cambridge, UK and New York: Cambridge University Press.

John XXIII. Pacem in Terris, 1963.

John Paul II. Laborem Exercens, 1981.

John Paul II. Centesimus Annus, 1991.

John Paul II. Sollicitudo Rei Socialis, 1987.

Kander, Astrid, Paolo Malanima, Paul Warde. Power to the People: Energy in Europe over the Last Five Centuries. Princeton: Princeton University Press, 2013.

Keys, Mary M. Aquinas, Aristotle and the Promise of the Common Good. Cambridge: Cambridge University Press, 2008.

Koterski, Joseph. 'Human Nature from a Catholic Perspective', American Journal of Economics and Sociology, 71:4 (2012), pp. 809-839.

Langan, John, S.J. 'Common Good', in A New Dictionary of Christian Ethics, edited by John Macquarrie, James Childress. London: SCM Press, 1986, p. 102.

Lavere, George J. 'The problem of the common good in Saint Augustine's Civitas Terrena', Augustinian Studies, 14 (1983), pp. 1-10.

Leo XIII. Rerum Novarum. 1891.

Long, Steven A. 'Understanding the Common Good'. Nova et Vetera, 16:4 (2018), pp. 11351152. 
Lustig, B. Andrew. 'Property and Justice in the Modern Encyclical Literature', The Harvard Theological Review, 83:4 (Oct 1990), pp. 415-446.

Maritain, Jacques. Man and the State. Chicago: University of Chicago Press 1951.

Mount, Eric, Jr. Covenant, Community, and the Common Good: An Interpretation of Christian Ethics. Cleveland, OH: Pilgrim Press, 1999.

Murray, John Courtney. We Hold These Truths: Catholic Reflections on the American Proposition. New York: Sheed and Ward 1960.

Myers, Benjamin. 'Rights, Resistance and the Common Good: Calvin's Political Theology', Uniting Church Studies, 17:1 (2011), pp. 33-43.

Nussbaum, Martha C. Women and Human Development: The Capabilities Approach, Cambridge, UK: Cambridge University Press 2000.

Nussbaum, Martha C. Frontiers of Justice: Disability, Nationality, Species Membership. Cambridge, MA, London, UK: The Belknap Press of Harvard University Press 2006.

Nussbaum, Martha C. 'Chapter 14: Human Dignity and Political Entitlements', in Human Dignity and Bioethics: Essays Commisioned by the President's Council on Bioethics. Washington, D.C.: 2008.

Nussbaum, Martha C. Creating Capabilities: The Human Development Approach. Cambridge, MA: The Belknap Press of Harvard University Press 2011.

Oderberg, David S. "The Metaphysical Foundations of Natural Law" in Natural Moral Law in Contemporary Society, edited by Holger Zaborowski. Washington, D.C.: Catholic University of America Press, 2010, pp. 44-75.

Pally, Marcia. The New Evangelicals: Expanding the Vision of the Common Good. Rapids, MI: Eerdmans, 2011

Paul VI. Gaudium et Spes. 1965.

Pontifical Council for Justice and Peace, Compendium of the Social Doctrine of the Church, 2004.

Pontifical Council for Justice and Peace. Energy, Justice, and Peace: A Reflection on Energy in the Current Context of Development and Environmental Protection. New York: Paulist Press 2014.

Rasmussen, Larry L. 'Energy: the Challenges to and from Religion', Zygon, 46:4 (December 2011), pp. 985-1002.

Scheid, Daniel P. The Cosmic Common Good: Religious Grounds for Ecological Ethics. Oxford: Oxford University Press 2016.

Schweiker, William (ed.). The Blackwell Companion to Religious Ethics. Malden, MA: Blackwell 2008.

Sovacool, Benjamin K. Energy \& Ethics: Justice and the Global Energy Challenge. New York: Palgrave Macmillan 2013.

Sovacool, Benjamin K., Michael H. Dworkin. Global Energy Justice: Problems, Principles, and Practices. Cambridge, UK: Cambridge University Press, 2014.

Spieker, Manfried. 'The Universal Destination of Goods: The Ethics of Property in the Theory of a Christian Society', Journal of Markets $\mathcal{E}$ Morality, 8:2 (Fall 2005), pp. 333-354.

Taebi, Behnam and Sabine Roeser (eds.). The Ethics of Nuclear Energy: Risk, Justice, and Democracy in the post-Fukushima Era. Cambridge: Cambridge University Press 2015.

The webpage of the International Energy Agency, https://www.iea.org/energyaccess/ (accessed 2018-06-20).

Thomson, Harriet, Carolyn Snell, Stefan Bouzarovski. 'Health, Well-Being and Energy Poverty in Europe: A Comparative Study of 32 European Countries', International Journal of Environmental Research and Public Health, 14, 584, 2017, pp. 1-20. 
De Ethica. A Journal of Philosophical, Theological and Applied Ethics Vol. 6:1 (2020)

United Nations, Department of Economic and Social Affairs, Population Division. World Population Prospects: the 2017 Revision, Key Findings and Advance Tables, Working Paper No. ESA/P/WP/248. UN: New York 2017. 
De Ethica. A Journal of Philosophical, Theological and Applied Ethics Vol. 6:1 (2020) 